\title{
ZnCdS:Cu,Al,Cl: A Near Infra-Red Emissive Family of Phosphors for Marking, Coding, and Identification
}

\author{
J. Silver, P. J. Marsh, G. R. Fern, T. G. Ireland, ${ }^{\mathrm{z}}$ and A. Salimian \\ Wolfson Centre for Materials Processing Incorporating the Centre for Phosphors and Display Materials, Institute of \\ Materials and Manufacturing, Brunel University London, Uxbridge, Middlesex UB8 3PH, United Kingdom
}

\begin{abstract}
$\mathrm{Zn}_{1-\mathrm{x}} \mathrm{Cd}_{\mathrm{x}}: \mathrm{Cu}_{0.03 \%}, \mathrm{Cl}$ (where $\mathrm{x}=0.5-0.9$ ) infrared emitting phosphors have been synthesized by an aqueous thermal decomposition method. The aim was to developing infrared emitting phosphors for coding, marking, and identification applications. The phosphors were characterized by, X-ray powder diffraction, scanning electron microscopy and photoluminescence spectroscopy. The emission band at $1000 \mathrm{~nm}$ was sufficiently far into the infrared region that visible emission was minimized. Co-doping $\mathrm{Zn}_{1-\mathrm{x}} \mathrm{Cd}_{\mathrm{x}} \mathrm{S}: \mathrm{Cu}_{0.03 \%}$ with $\mathrm{Al}^{3+}$ increased the infrared emission intensity to over twice that of the equivalent $\mathrm{Zn}_{0.3} \mathrm{Cd}_{0.7} \mathrm{~S}: \mathrm{Cu}_{0.03 \%}$ phosphor (with no $\mathrm{Al}^{3+}$ ion co-doping), with the highest intensity being found for the phosphor composition $\mathrm{Zn}_{0.1} \mathrm{Cd}_{0.9} \mathrm{~S}: \mathrm{Cu}_{0.03 \%}, \mathrm{Al}_{0.03 \%}$. It is shown herein that the inclusion of $\mathrm{Al}^{3+}$ into the phosphors causes the formation of cells with smaller cell volume, and it is suggested that this is the prerequisite for the improved photoluminescent properties. Finally we have shown herein that these infrared emitting powder phosphors are thus able to meet marking and coding requirements, especially in low light and poor visibility.

(C) The Author(s) 2017. Published by ECS. This is an open access article distributed under the terms of the Creative Commons Attribution 4.0 License (CC BY, http://creativecommons.org/licenses/by/4.0/), which permits unrestricted reuse of the work in any medium, provided the original work is properly cited. [DOI: 10.1149/2.0131801jss] All rights reserved.

(cc) BY
\end{abstract}

Manuscript submitted June 27, 2017; revised manuscript received August 23, 2017. Published September 16, 2017. This paper is part of the JSS Focus Issue on Visible and Infrared Phosphor Research and Applications.

Although the uses of phosphors are widespread in modern technologies and they are common in the display and lighting industries where products find applications in both domestic and commercial applications, their use in other areas is less widely appreciated. Such uses include:- on postage stamps to help letter sorting, on currency and bank notes for secrecy/authenticity, thermometry, luminescent paints and glow in the dark toys. In addition there are a number of military applications.

Recently the wide availability of near-ultraviolet light and visible light emitting diodes (LEDs) and laser diodes in addition to infrared emitting systems has made the remote excitation of infrared emitting phosphors a practical possibility. Infrared emitting powder phosphors have the potential to meet marking and coding requirements, especially in low light and poor visibility.

The advantages of IR emitting powder phosphors are:-

1) That they can be easily deposited by conventional techniques to form large areas, if required, either by simple settling techniques, or by inclusion in a binder suitable for screen or ink-jet printing (the binder of course must be transparent over the required spectral range).

2) Such deposited powder layers, depending on their thickness and particle size and particle morphology etc., can be used in a transmission or a reflective mode with suitable $\mathrm{UV}$ or visible excitation sources.

The ease of fabrication and the wide excitation spectra of the phosphors as well as their efficiencies facilitate a wide range of potential applications, including the following as preliminary examples:

a) For use in coding/marking systems as simple IR sensitive markers.

b) For improved marking/detection in conjunction with night vision systems.

The origins of the green luminescence in $\mathrm{ZnS}: \mathrm{Cu}$ phosphors (where $\mathrm{Cu}$ is introduced as a dopant into the $\mathrm{ZnS}$ lattice) has been attributed to a luminescent center consisting of an activator $(\mathrm{A}-$ acceptor $)(\mathrm{Cu})$ and a co-activator (D - donor) ( $\mathrm{Al}$ or halide). Luminescence arises from transitions from the D level to the A level.

It has been reported that by increasing the cadmium concentration in $\mathrm{Zn}_{1-\mathrm{x}} \mathrm{Cd}_{\mathrm{x}} \mathrm{S}$ solid solutions the photoluminescence emission band can

${ }^{\mathrm{z}}$ E-mail: Terry.ireland@brunel.ac.uk be moved to longer wavelengths This is because the bandgap energy $\left(\mathrm{E}_{\mathrm{g}}\right)$ decreases with increasing cadmium concentration, from $3.91 \mathrm{eV}$ for $\mathrm{ZnS}$ to $2.58 \mathrm{eV}$ in $\mathrm{CdS}$. ${ }^{2}$ Werring et al. used $\mathrm{Zn}_{0.4} \mathrm{Cd}_{0.6} \mathrm{~S}: \mathrm{Cu}$ with an emission peak at $\sim 900 \mathrm{~nm}$ in order to match with the absorption peak of a silicon thyristor for use in an infrared switching device. ${ }^{3}$

It has been shown that by varying the zinc to cadmium ratio, fine tuning of the wavelength of the photoluminescent emission band can be achieved. ${ }^{2-6}$ A major requirement for the purpose of this work was to move the emission peak of the phosphor sufficiently far into the infra-red region so that visible light emission was minimized resulting from the high energy side of the band was minimized, whilst maintaining sufficient intensity at infrared wavelengths which could be detectable by night vision systems.

$\mathrm{Zn}_{1-\mathrm{x}} \mathrm{Cd}_{\mathrm{x}} \mathrm{S}: \mathrm{Cu}$ phosphors with higher cadmium concentrations higher than $\mathrm{Zn}_{0.4} \mathrm{Cd}_{0.6} \mathrm{~S}: \mathrm{Cu}$ were selected for this study with the aim that the increased cadmium concentration would result in the emission band being moved sufficiently far into the near infrared region. We have previously reported the synthesis and properties of the infrared emitting $\mathrm{ZnCdS}: \mathrm{Cu}, \mathrm{In}, \mathrm{Cl}$ phosphors. ${ }^{7,8}$ In addition we have also reported brief details of this $\mathrm{Zn}_{1-\mathrm{x}} \mathrm{Cd}_{\mathrm{x}} \mathrm{S}: \mathrm{Cu}, \mathrm{Al}, \mathrm{Cl}$ phosphor system, ${ }^{9}$ but in this work we present a much more complete study.

For a number of years $\mathrm{Al}^{3+}$ has been added as a co-dopant to green emitting $\mathrm{ZnS}: \mathrm{Cu}$ phosphors that have been used in cathode ray tube (CRT) devices. ${ }^{10-12}$ In addition, $\mathrm{ZnS}: \mathrm{Cu}, \mathrm{Al}$ has been investigated for use in low voltage field emission devices, ${ }^{13}$ as nanocrystals ${ }^{14}$ and as quantum dots (QDs). ${ }^{15}$ From these studies on co-doping with $\mathrm{Al}^{3+}$ that reported the visible photoluminescence properties of $\mathrm{ZnS}: \mathrm{Cu}, \mathrm{Al}$ it was apparent that the dopant confers useful attributes when it is added. We therefore report herein the effects on the photoluminescent emission of $\mathrm{Zn}_{1-\mathrm{x}} \mathrm{Cd}_{\mathrm{x}} \mathrm{S}: \mathrm{Cu}, \mathrm{Cl}$ infrared emitting phosphors when co-doped with $\mathrm{Al}^{3+}$ cations. Previously we have also reported brief details of this $\mathrm{Zn}_{1-\mathrm{x}} \mathrm{Cd}_{\mathrm{x}} \mathrm{S}: \mathrm{Cu}, \mathrm{Al}, \mathrm{Cl}$ phosphor system, ${ }^{9}$ but in this work we present a much more complete study.

It is worthwhile before proceeding into the paper to consider the effect of cadmium in the environment as we are suggesting its use in these infra-red emitting phosphors. In the last decade or so nearinfrared emitting lead-based quantum dots (QD) have been the subject of considerable attention due to their potential applications in for instance solar cells, bio-imaging, telecommunications, and quantum computing. ${ }^{16}$ Such QDs can be tuned to emit from 750 to $3700 \mathrm{~nm}$ which at first site appears to make them very good candidates for these applications, however there are a number of drawbacks even allowing for the fact that improving synthetic methods have led to fairly 
uniform and narrow size distribution of these lead-based quantum dots, The drawbacks include price of the QDs, the fact that they are often lead based (which makes them toxic and a possible environmental hazard) and of course their stability under atmospheric conditions which is a challenge. The stability of these QDs can be improved by the application of a passivation shell which is normally grown over the QDs to form a core/shell structure which in turn improves the stability, but toxicity and price is still an issue. It is worth mentioning that other QDs (not lead based) have problems. For example, the emission bands from $\mathrm{CdSeTe} / \mathrm{ZnS},{ }^{17} \mathrm{CdTe} / \mathrm{CdS},{ }^{18} \mathrm{CdSeTe} / \mathrm{CdS},{ }^{19}$ $\mathrm{CdSeTe},{ }^{20}$ and $\mathrm{ZnS} / \mathrm{CdS}^{21,22}$ QDs are not sufficiently far enough into the infrared region $(\sim 800-850 \mathrm{~nm})$ for them to have been considered for investigation herein.

An objection often raised against cadmium containing phosphors is that cadmium is toxic and therefore an environmental hazard. In 2015 , Coe-Sullivan ${ }^{23}$ put forward an interesting defence of the use of cadmium in QDs that are used in high value QDLED displays he pointed out that the amount of $\mathrm{Cd}$ present was small and moreover, the quantity compared to the level in the environment as a result of burning fossil fuels, is in fact miniscule and therefore not an issue. Indeed cadmium containing QDs have been employed/proposed for a range of applications in, for example, bio-imaging. ${ }^{24,25}$

In the last fifteen years, there has been significant research and development in biomedical imaging and diagnostics applications using semiconductor nanocrystals with near-infrared (NIR) absorption and emission spectra. ${ }^{26-29}$ In comparison to visible emitting QDs, NIR nanocrystals with emission spectra in the 700-1700 $\mathrm{nm}$ spectral range have advantages including reduced photochemical damage and enhanced tissue penetration. However such nanocrystals have found only limited uses in biology and medicine because of their inherent disadvantages such as low quantum yields large particle sizes, poor photo-stability, or broad emission spectra. In contrast, the more established visible light emitting QDs have very different physical dimensions (they are smaller by a factor of 3-4 in diameter, and by a factor of 27-64 in volume), that can still cause problems such as large variations in steric hindrance, signal brightness, and binding kinetics in biological environments. ${ }^{30-32}$ The point of interest is that such Cd containing QDs should even be considered for such uses suggests these materials are not considered to be such a health hazard. It should be noted that in the $\mathrm{Zn}_{1-\mathrm{x}} \mathrm{Cd}_{\mathrm{x}} \mathrm{S}: \mathrm{Cu}, \mathrm{Al}, \mathrm{Cl}$ phosphors discussed below (although containing significantly more Cd than the QDs) would only be used if they were in confined either by coating or other means so they would not be an environmental pollutant.

\section{Experimental}

Materials._Thiourea dioxide (TDO), formamidinesulfinic acid), cadmium acetate, zinc acetate dihydrate, aluminum chloride and copper acetate were obtained from Sigma Aldrich. All chemicals were used as supplied.

Synthesis of $\mathrm{Zn}_{1-x} \mathrm{Cd}_{x} S: C u_{0.03}, A l_{0.03}, \mathrm{Cl}$ and $\mathrm{Zn}_{1-x} \mathrm{Cd}_{x} S: C u_{0.03}, \mathrm{Cl}$ and (where $x=0.5-0.9)$. - The thermal decomposition of aqueous TDO solutions, in the presence of $\mathrm{Zn}^{2+}$ and $\mathrm{Cd}^{2+}$, was used as the method of choice for the precipitation of doped $\mathrm{ZnCdS}$ phosphor precursors. We have previously employed thermal aqueous TDO decomposition in the preparation of $\mathrm{ZnS}: \mathrm{Cu}, \mathrm{Cl}$ for cathode ray tube phosphor applications. ${ }^{33}$

Cadmium acetate and zinc acetate dihydrate $(0.05$ moles in total) were dissolved in water. Aqueous copper acetate solution $(15 \mathrm{ml}$, $0.001 \mathrm{M}$ ), and where appropriate, aqueous aluminum chloride solution $(0.001 \mathrm{M})$ were added. The solution was heated, with stirring to boiling. TDO ( 1 mole, $108.12 \mathrm{~g}$ ) was added. Once precipitation had begun, the heating was continued for 1 hour. The mixture was allowed to cool, and filtered. The precipitate was air dried at $\sim 100^{\circ} \mathrm{C}$, then fired with sodium chloride ( $2 \%$ of the mass of the precipitate) at $880^{\circ} \mathrm{C}$ for 1 hour. The fired phosphor was washed with boiling glacial acetic acid/water (1:1 ratio) to remove any zinc oxide that may have formed during the firing process, then dried and used. Samples of these phos- phors that were prepared 14 years ago and kept in polythene sample bags with no additional protection from the general atmosphere still work well. This shows they are not affected badly by moisture or oxygen. This is unlike CaS:Eu red phosphors that decay rapidly in the atmosphere. $^{34}$

$X$-ray powder diffraction and scanning electron microscopy.$\mathrm{X}$-ray powder diffraction measurements were made using a Bruker D8 powder diffractometer fitted with a nickel-filtered copper source and a LynxEye silicon strip detector. Data were recorded from 5 to $100^{\circ} 2 \theta$ at $293 \mathrm{~K}$, and the data were fitted using a standard refinement method by means of a Bruker AXS TOPAS version 3 Rietveld refinement computer software. The background was refined using a Chebychev polynomial and a correction for $2 \theta$ was made using a National Institute of Standards and Technology standard calibrant. Scanning electron microscope images were obtained by utilising a Zeiss Supra 35VP scanning electron microscope.

Photoluminescence (PL) measurements.-Photoluminescent measurements were carried out using a Horiba Scientific Fluorolog spectrofluorometer- Horiba iHR 320 spectrometer system. The Fluorolog-3 spectrofluorometer comes equipped with a $450 \mathrm{~W}$ XE OFR short arc xenon lamp mounted vertically in an air-cooled housing; light collection and focusing are achieved by an off-axis mirror for maximum efficiency at all wavelengths. The monochromators are $f / 3.6$ Czerny-Turner design with kinematic classically-ruled gratings with a $0.3 \mathrm{~nm}$ resolution and all-reflective optics. The system has a double-grating excitation monochromator and single-grating emission monochromator. The automatic slits are continuously controlled via computer with settings from 0 to $30 \mathrm{~nm}$. The system has a reference photodiode for excitation correction from $200 \mathrm{~nm}$ to $980 \mathrm{~nm}$ and a room-temperature side-on R928P emission detector for high sensitivity in photon-counting mode $(180 \mathrm{~nm}$ to $850 \mathrm{~nm})$. Linearity to $2 \times 106 \mathrm{cps} ;<1000$ dark counts per second.

Blue laser diode.-A blue laser diode (Wicked Lasers, Model No.ARC44501, Kowloon, Hong Kong) emission wavelength $445 \mathrm{~nm}$ was used to excite the phosphors for imaging of their visible and infrared emissions.

Night vision system.-The infrared emissions from the phosphor were imaged using a generation 2 PNP-pocket scope night vision system (Pyser-SGI Ltd., Melbourne, Australia). The night vision images were collected with a digital camera (Panasonic MDC-FS35, Osaka, Japan. A long wave pass filter (Medway Optics Ltd., Chatham, UK, cut-on of $900 \mathrm{~nm}$ ) was used to observe the pure infrared emission of the phosphor above $900 \mathrm{~nm}$. To eliminate the strong blue emissions from the laser diode a filter with a cutoff from $315 \mathrm{~nm}$ to $535 \mathrm{~nm}$ was obtained (Univet Optical Technologies, Rezzato, Italy).

\section{Results and Discussion}

X-ray powder diffraction data.-The X-ray powder diffraction data of $\mathrm{Zn}_{0.4} \mathrm{Cd}_{0.6} \mathrm{~S}: \mathrm{Cu}_{0.03}, \mathrm{Al}_{0.03}, \mathrm{Cl}$ is displayed in Figure 1 (where the major peaks are indexed). The powder diffraction data was in good agreement with known values for a similar zinc cadmium sulfide compound $\left(\mathrm{Zn}_{1.95} \mathrm{Cd}_{0.805} \mathrm{~S}\right.$, PDF 2011 PDF 00-040-0835). It is likely that the disorder in the diffractogram, which was evidenced by the broadening of the base of the diffraction peaks, was due to the compound being composed of a mixture of zinc sulfide and cadmium sulfide lattices which have difference in lattice constant of approximately $10 \%{ }^{35}$ In Table I the cell constants and cell volumes as well as the percentage of each cell present are presented for each phosphor that was synthesized. In all cases the cells present were fitted to hexagonal wurtzite type cells known as the "Greenockite" type structures. Plots of the average volume for each phase against the $\% \mathrm{Cd}$ present are presented in Figure 2 for the two sets of materials (those containing $\mathrm{Al}^{3+}$ and those that do not). Weighted cell volumes were derived by multiplying the cell volume by the percentage of each cell present 


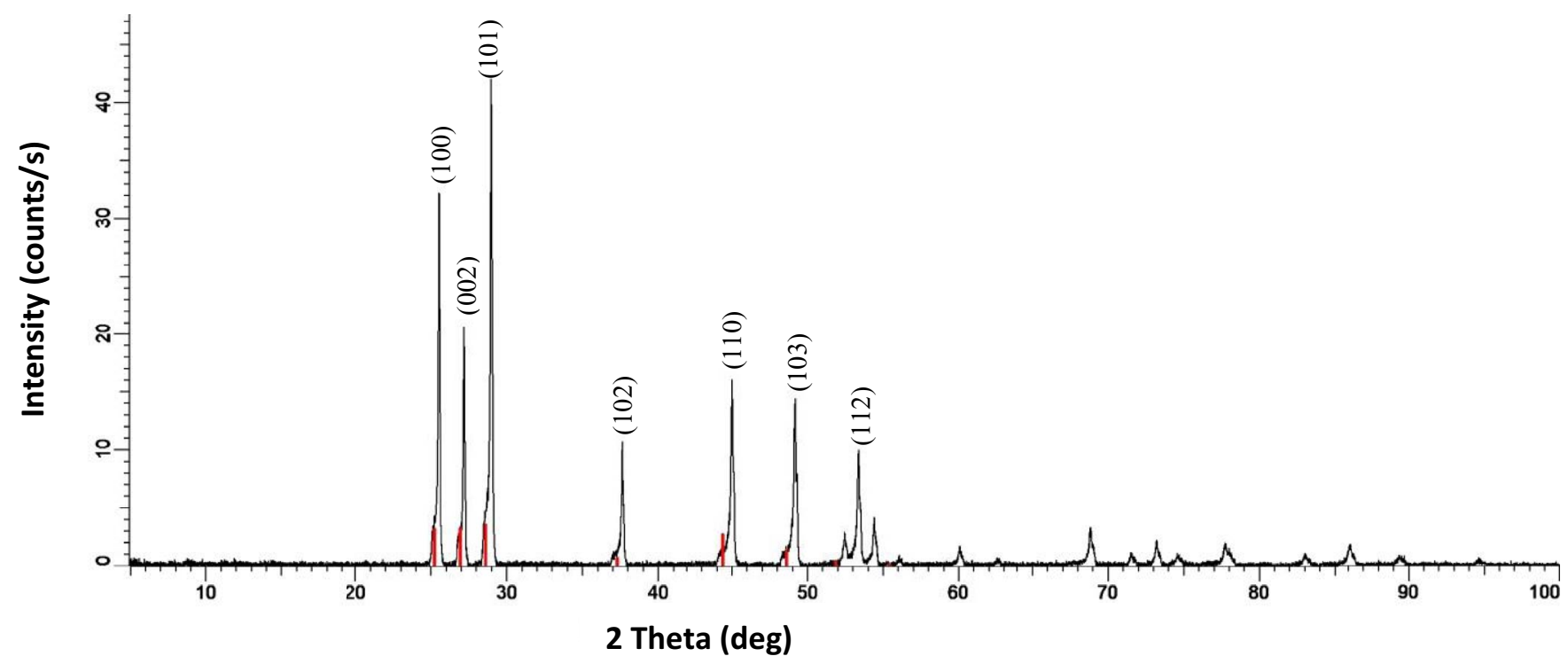

Figure 1. X-ray powder diffraction data of $\mathrm{Zn}_{0.4} \mathrm{Cd}_{0.6} \mathrm{~S}: \mathrm{Cu}_{0.03}, \mathrm{Al}_{0.03}, \mathrm{Cl}$, presented with the known values of $\mathrm{Zn}_{1.95} \mathrm{Cd}_{0.805} \mathrm{~S}$ (PDF 2011 PDF 00-040-0835) shown by the red lines.

and then adding them together. These cell volumes are only used for the plot presented in Figure 2 of cell volume against percentage of $\mathrm{Cd}$ content, and thus no errors are calculated for them. It is apparent from Figure 2 that the phosphors containing the $\mathrm{Al}^{3+}$ cations manifest smaller cell sizes than those that do not. This finding indicates that the $\mathrm{Al}^{3+}$ cations are responsible for the observed contraction in the cell sizes.

Field emission scanning electron microscopy.-The scanning electron microscope image in Figure 3 shows particles of $\mathrm{Zn}_{0.4} \mathrm{Cd}_{0.6} \mathrm{~S}: \mathrm{Cu}_{0.03}, \mathrm{Al}_{0.03}, \mathrm{Cl}$, the size and morphology of these particles (1-6 $\mu \mathrm{m}$ diameter) were typical of the size and morphology of all particles prepared in this work. The relatively small particles may be advantageous for production and application of inks based on this phosphor. Such inks could be used for the production of large area infrared emission panels. The ability to simply print a new design for a large area emissive panel as required would be advantageous in terms of cost and ease of modification compared to using large arrays of infrared emitting LEDs.

Photoluminescence studies.-It has been established that $\mathrm{ZnS}: \mathrm{Cu}$, $\mathrm{Cl}$ has a green emission peak which is shifted to longer wavelength by about $60-70 \mathrm{~nm}$ compared to $\mathrm{ZnS}: \mathrm{Cl}^{36}$ which means that a lower cadmium concentration would be required to reach a specified wavelength in the infrared region for $\mathrm{Zn}_{1-x} \mathrm{Cd}_{\mathrm{x}} \mathrm{S}: \mathrm{Cu}, \mathrm{Cl}$ compared to $\mathrm{Zn}_{1-\mathrm{x}} \mathrm{Cd}_{\mathrm{x}} \mathrm{S}: \mathrm{Cl}$.

Table I. Powder XRD data for $\mathrm{Zn}_{1-\mathrm{x}} \mathrm{Cd}_{\mathrm{x}} \mathrm{S}: \mathrm{Cu}_{0.03}, \mathrm{Al}_{0.03}, \mathrm{Cl}$ and $\mathrm{Zn}_{1-\mathrm{x}} \mathrm{Cd} \mathrm{d}_{\mathrm{x}} \mathrm{S}: \mathrm{Cu}_{0.03}, \mathrm{Cl}$ (where $\left.\mathrm{x}=0.5-0.9\right)$.

\begin{tabular}{|c|c|c|c|c|c|}
\hline Formula & a $(\AA)$ & c $(\AA)$ & $\%$ phase present & Cell Volume & Weighted Cell Volume \\
\hline \multirow[t]{3}{*}{$\mathrm{Zn}_{0.5} \mathrm{Cd}_{0.5} \mathrm{~S}: \mathrm{Cu}_{0.03 \%}, \mathrm{Cl}$} & $4.0197(19)$ & $6.551(3)$ & $45.83(2) \%$ & $91.67(10)$ & \multirow[t]{3}{*}{94.00} \\
\hline & $4.048(2)$ & $6.593(3)$ & $22.51(2) \%$ & $93.55(11)$ & \\
\hline & $4.1091(19)$ & $6.681(3)$ & $31.66(19) \%$ & $97.69(10)$ & \\
\hline \multirow[t]{3}{*}{$\mathrm{Zn}_{0.4} \mathrm{Cd}_{0.6} \mathrm{~S}: \mathrm{Cu}_{0.03 \%}, \mathrm{Cl}$} & $4.057(3)$ & $6.606(4)$ & $38.25(2) \%$ & $94.16(14)$ & \multirow[t]{3}{*}{96.05} \\
\hline & $4.126(3)$ & $6.702(5)$ & $24.08(2) \%$ & $98.82(15)$ & \\
\hline & $4.087(3)$ & $6.650(5)$ & $37.67(3) \%$ & $96.20(15)$ & \\
\hline \multirow[t]{3}{*}{$\mathrm{Zn}_{0.3} \mathrm{Cd}_{0.7} \mathrm{~S}: \mathrm{Cu}_{0.03 \%}, \mathrm{Cl}$} & $4.105(3)$ & $6.672(5)$ & $64.71(3) \%$ & $97.37(15)$ & \multirow[t]{3}{*}{97.66} \\
\hline & $4.127(3)$ & $6.705(5)$ & $26.83(3) \%$ & $98.92(15)$ & \\
\hline & $4.084(3)$ & $6.643(5)$ & $8.46(3) \%$ & $95.94(16)$ & \\
\hline \multirow[t]{3}{*}{$\mathrm{Zn}_{0.2} \mathrm{Cd}_{0.8} \mathrm{~S}: \mathrm{Cu}_{0.03 \%}, \mathrm{Cl}$} & $4.131(4)$ & $6.708(7)$ & $64.51(5) \%$ & $99.2(2)$ & \multirow[t]{3}{*}{98.55} \\
\hline & $4.110(4)$ & $6.685(7)$ & $30.60(5) \%$ & $97.8(2)$ & \\
\hline & $4.065(5)$ & $6.609(9)$ & $4.89(2) \%$ & $94.6(3)$ & \\
\hline \multirow[t]{2}{*}{$\mathrm{Zn}_{0.1} \mathrm{Cd}_{0.9} \mathrm{~S}: \mathrm{Cu}_{0.03 \%}, \mathrm{Cl}$} & $4.1325(11)$ & $6.7102(18)$ & $75.11(4) \%$ & $99.24(6)$ & \multirow[t]{2}{*}{98.97} \\
\hline & $4.1184(12)$ & $6.683(2)$ & $24.89(4) \%$ & $98.16(6)$ & \\
\hline \multirow[t]{3}{*}{$\mathrm{Zn}_{0.5} \mathrm{Cd}_{0.5} \mathrm{~S}: \mathrm{Cu}_{0.03 \%}, \mathrm{Al}_{0.03 \%} \mathrm{Cl}$} & $4.0007(3)$ & $6.5201(6)$ & $68.21(19) \%$ & $90.379(18)$ & \multirow[t]{3}{*}{91.02} \\
\hline & $4.0167(4)$ & $6.5453(8)$ & $22.31(18) \%$ & $91.45(2)$ & \\
\hline & $4.0635(6)$ & $6.6186(15)$ & $9.48(11) \%$ & $94.64(4)$ & \\
\hline \multirow{3}{*}{$\mathrm{Zn}_{0.4} \mathrm{Cd}_{0.6} \mathrm{~S}: \mathrm{Cu}_{0.03 \%}, \mathrm{Al}_{0.03 \%} \mathrm{Cl}$} & $4.0243(8)$ & $6.5543(13)$ & $69.67(2) \%$ & $91.93(4)$ & \multirow[t]{3}{*}{92.66} \\
\hline & $4.0810(9)$ & $6.6378(18)$ & $14.58(17) \%$ & $95.74(5)$ & \\
\hline & $4.0404(10)$ & $6.5816(18)$ & $15.75(2) \%$ & $93.05(5)$ & \\
\hline $\mathrm{Zn}_{0.2} \mathrm{Cd}_{0.8} \mathrm{~S}: \mathrm{Cu}_{0.03 \%}, \mathrm{Al}_{0.03 \%} \mathrm{Cl}$ & $4.0931(7)$ & $6.6538(12)$ & $100.000 \%$ & $96.54(4)$ & 96.54 \\
\hline $\mathrm{Zn}_{0.1} \mathrm{Cd}_{0.9} \mathrm{~S}: \mathrm{Cu}_{0.03 \%}, \mathrm{Al}_{0.03 \%} \mathrm{Cl}$ & 4.1192656 & 6.6898981 & $100.000 \%$ & 98.30820 & 98.31 \\
\hline
\end{tabular}

Weighted cell volumes were derived by multiplying the cell volume by the percentage of each cell present and then adding them together. These cell volumes are only used for the plot presented in Figure 2 of cell volume against percentage of Cd content, and thus no errors are calculated for them. 


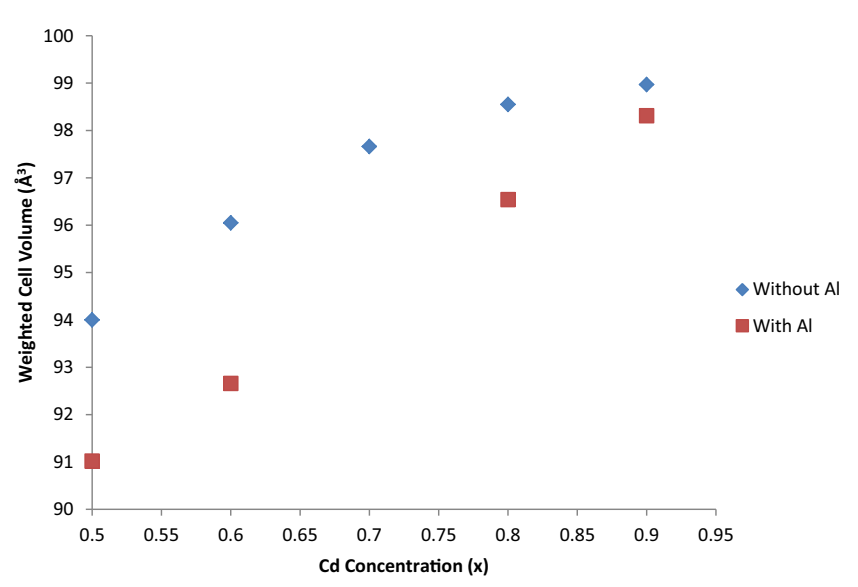

Figure 2. Plot of mean weighted cell volume vs Cd concentration (x) for $\mathrm{Zn}_{1-\mathrm{x}} \mathrm{Cd}_{\mathrm{x}} \mathrm{S}: \mathrm{Cu}_{0.03}, \mathrm{Al}_{0.03}, \mathrm{Cl}$ and $\mathrm{Zn}_{1-\mathrm{x}} \mathrm{Cd}_{\mathrm{x}} \mathrm{S}: \mathrm{Cu}_{0.03}, \mathrm{Cl}$ (where $\left.\mathrm{x}=0.5-0.9\right)$.

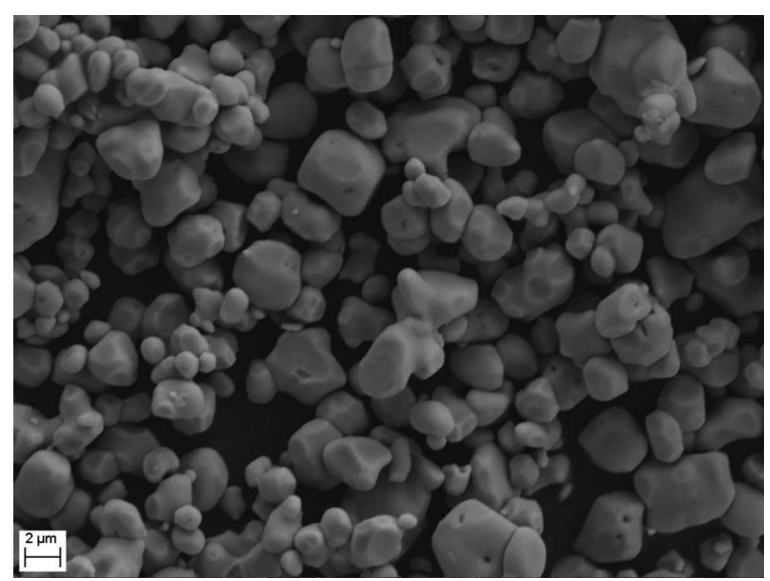

Figure 3. SEM image of $\mathrm{Zn}_{0.4} \mathrm{Cd}_{0.6} \mathrm{~S}: \mathrm{Cu}_{0.03}, \mathrm{Al}_{0.03}, \mathrm{Cl}$ particles.

The photo-luminescent excitation (PLE) spectra, at $1000 \mathrm{~nm}$ emission, of $\mathrm{Zn}_{1-\mathrm{x}} \mathrm{Cd}_{\mathrm{x}} \mathrm{S}: \mathrm{Cu}_{0.03}, \mathrm{Al}_{0.03}, \mathrm{Cl}$ (where $\mathrm{x}=0.5-0.9$ ) phosphors are presented in Figure 4, and the corresponding PL emission spectra in Figure 5.

For each of the phosphors with the zinc/cadmium ratios in the excitation spectrum (Figure 4 ) there was a broad peak at $\sim 365 \mathrm{~nm}$ and a more intense sharp peak between $\sim 460-505 \mathrm{~nm}$ which shifts to longer wavelengths with increasing cadmium concentration, and an

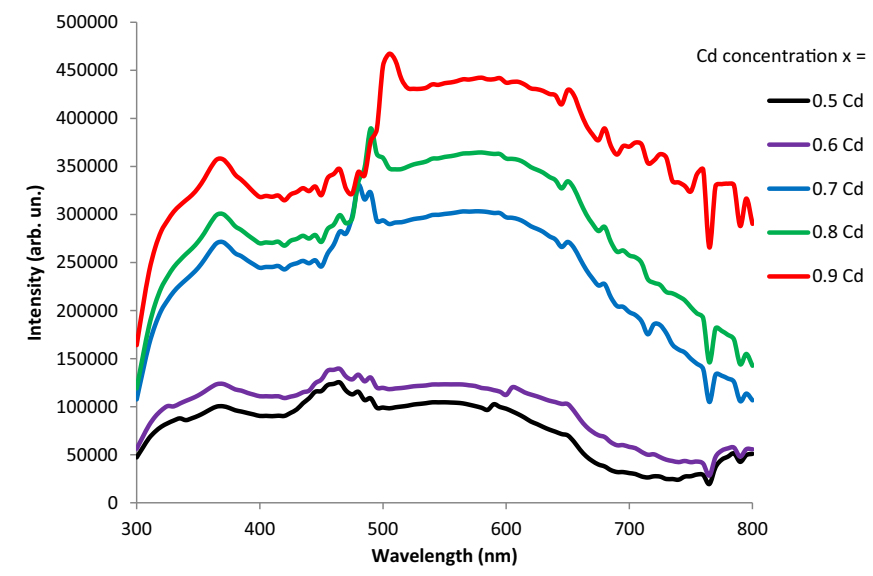

Figure 4. PLE spectra, at $1000 \mathrm{~nm}$ emission of $\mathrm{Zn}_{1-\mathrm{x}} \mathrm{Cd}_{\mathrm{x}} \mathrm{S}: \mathrm{Cu}_{0.03}, \mathrm{Al}_{0.03}, \mathrm{Cl}$ (where $\mathrm{x}=0.5-0.9$ ) phosphors.

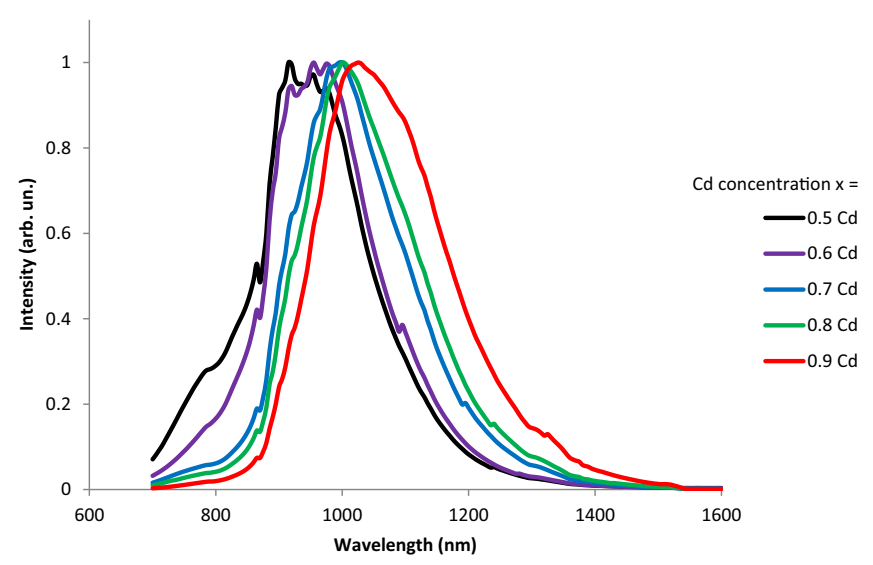

Figure 5. Normalized PL spectra, under $580 \mathrm{~nm}$ excitation, of $\mathrm{Zn}_{1-\mathrm{x}} \mathrm{Cd}_{\mathrm{x}} \mathrm{S}: \mathrm{Cu}_{0.03}, \mathrm{Al}_{0.03}, \mathrm{Cl}$ (where $\mathrm{x}=0.5-0.9$ ) phosphors.

intense very broad excitation band between $\sim 520 \mathrm{~nm}$ and $\sim 645 \mathrm{~nm}$. The relatively strong excitation band at $\sim 365 \mathrm{~nm}$ facilitates the use of long wavelength UV lamps and UV emitting LEDs as backlights when they are used in infrared emission panels and the broad excitation in the blue region means that phosphors could also be excited by blue light emitting LEDs. The fact that the PLE spectra are broad and cover most of the visible range means these phosphors can be excited by most wavelengths of visible light between $400 \mathrm{~nm}$ and $650 \mathrm{~nm}$.

Addition of $\mathrm{Al}^{3+}$ ions as a co-dopant resulted in blueshift in emission intensity (see Figure 5) compared to the corresponding $\mathrm{Zn}_{1-\mathrm{x}} \mathrm{Cd}_{\mathrm{x}} \mathrm{S}: \mathrm{Cu}_{0.03}, \mathrm{Cl}$ phosphors (see Figure 6). The shift to shorter wavelengths was $\sim 70 \mathrm{~nm}$ for $\mathrm{Zn}_{0.5} \mathrm{Cd}_{0.5} \mathrm{~S}: \mathrm{Cu}_{0.03}, \mathrm{Al}_{0.03}, \mathrm{Cl}$ but diminished as the cadmium concentration increased and the bandgap energy ( $\mathrm{E}_{\mathrm{g}}$ ) reduced. The blueshift for $\mathrm{Zn}_{0.9} \mathrm{Cd}_{0.1} \mathrm{~S}: \mathrm{Cu}, \mathrm{Al}, \mathrm{Cl}$ was $\sim 30 \mathrm{~nm}$. It should be noted that in both Figures 5 and 6 the phosphors were excited by orange light. It is also possible to excite them to emit infrared with most wavelengths across the visible spectrum (see their excitation spectra in Figure 4 and some additional Pl spectra excited at other wavelengths in Figure 7). The relative change in the intensity of the emission peak shown in Figure 7 indicates that the higher energy excitation wavelengths cause more intense emission in the infrared. It is apparent that for secret remote excitation then excitation sources giving out UV light can be used (see below for examples where a UV light source, or blue laser diodes are presented).

A comparison of the emission brightness of $\mathrm{Zn}_{1-\mathrm{x}} \mathrm{Cd}_{\mathrm{x}} \mathrm{S}$ : $\mathrm{Cu}_{0.03}, \mathrm{Al}_{0.03}, \mathrm{Cl}$ and $\mathrm{Zn}_{1-\mathrm{x}} \mathrm{Cd}_{\mathrm{x}} \mathrm{S}: \mathrm{Cu}_{0.03}, \mathrm{Cl}$ (where $\mathrm{x}=0.5-0.9$ ), is presented in Figure 8. For the phosphors which did not include $\mathrm{Al}^{3+}$ as a co-dopant, there was a small increase in emission intensity with

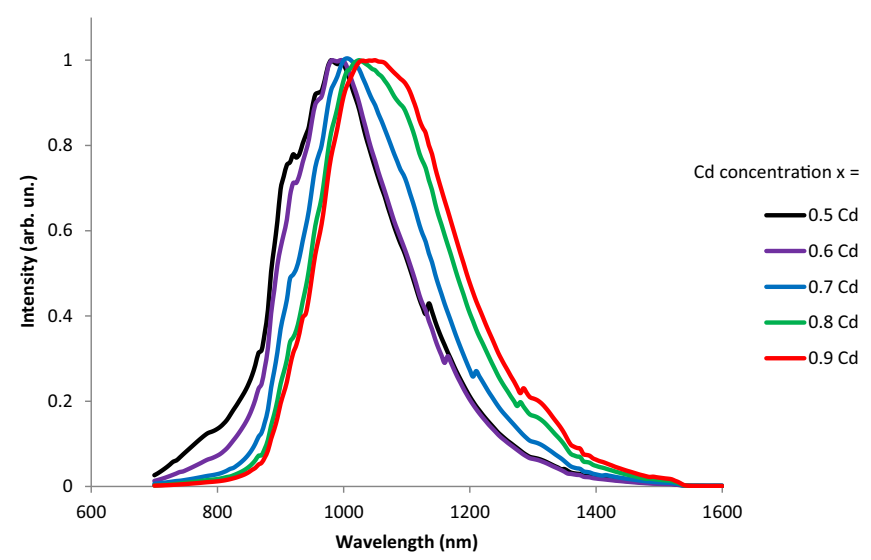

Figure 6. Normalized PL spectra, under $580 \mathrm{~nm}$ excitation, of $\mathrm{Zn}_{1-\mathrm{x}} \mathrm{Cd}_{\mathrm{x}} \mathrm{S}$ : $\mathrm{Cu}_{0.03}, \mathrm{Cl}$ (where $\mathrm{x}=0.5-0.9$ ) phosphors. 


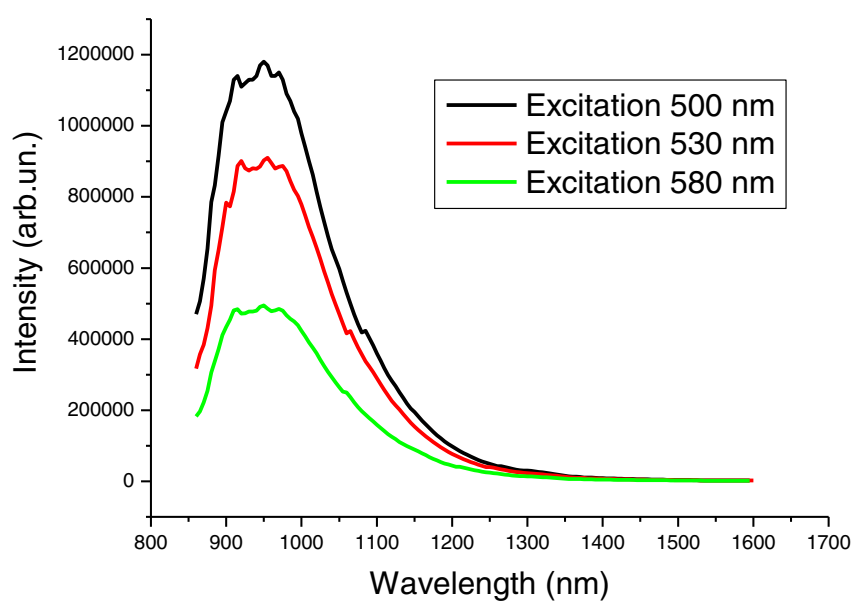

Figure 7. PL spectra, under $500 \mathrm{~nm}, 530 \mathrm{~nm}$ and $580 \mathrm{~nm}$ excitation, of $\mathrm{Zn}_{1-\mathrm{x}} \mathrm{Cd}_{\mathrm{x}} \mathrm{S}: \mathrm{Cu}_{0.03}, \mathrm{Cl}$ (where $\mathrm{x}=0.5-0.9$ ) phosphors. It is apparent that the intensity of the emission falls of as the excitation wavelength increases.

increasing cadmium concentrations which reached a plateau at the highest cadmium concentrations. In contrast, the presence of $\mathrm{Al}^{3+}$ ions resulted in a significant increase in the PL emission intensity at the highest cadmium concentrations. The PL emission peak of $\mathrm{Zn}_{0.1} \mathrm{Cd}_{0.9} \mathrm{~S}: \mathrm{Cu}_{0.03}, \mathrm{Al}_{0.03}, \mathrm{Cl}$ was more than twice as intense as the emission peak of $\mathrm{Zn}_{0.1} \mathrm{Cd}_{0.9} \mathrm{~S}: \mathrm{Cu}_{0.03}, \mathrm{Cl}$. At the higher cadmium concentrations, PL emission which may involve Al-Cu donor-acceptor pairs resulting in significantly brighter PL emission compared to PL emission from Cl-Cu donor-acceptor pairs. An alternative explanation to donor pairs is now discussed.

It is apparent from the fact that the phosphors containing $\mathrm{Al}^{3+}$ cations manifest the desired emission characteristics in both modifying the position of the emission and the enhanced emission intensity, that these properties originate from the presence of the $\mathrm{Al}^{3+}$ cations. The most likely explanation is that the cell contraction caused by the presence of the $\mathrm{Al}^{3+}$ cations observed in this work is the main cause of the change in the emission properties. Thus the copper cations experience stronger crystal fields in the smaller $\mathrm{Al}^{3+}$ containing lattices. These findings indicate that stronger or modified crystal fields cause both blue shifted emission and enhanced emission intensity. Moreover such crystal fields can be readily achieved by doping the lattice with additional small cations. Finally it may be that it is a combination of the smaller lattice squeezing the $\mathrm{Cu}$ cations and the $\mathrm{Al}-\mathrm{Cu}$ pairs that is responsible for the PL emission properties.

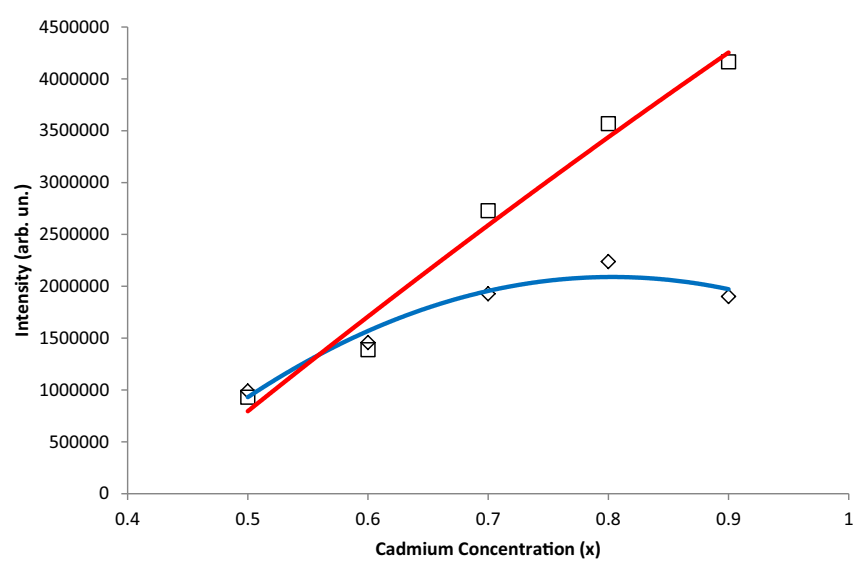

Figure 8. $\mathrm{PL}$ intensities of $\mathrm{Zn}_{1-\mathrm{x}} \mathrm{Cd}_{\mathrm{x}} \mathrm{S}: \mathrm{Cu}_{0.03}, \mathrm{Cl}$ phosphors $(\diamond)$ and $\mathrm{Zn}_{1-\mathrm{x}} \mathrm{Cd}_{\mathrm{x}} \mathrm{S}: \mathrm{Cu}_{0.03}, \mathrm{Al}_{0.03}, \mathrm{Cl}$ phosphors $(\square)$ with increasing cadmium concentrations $(\mathrm{x})$.
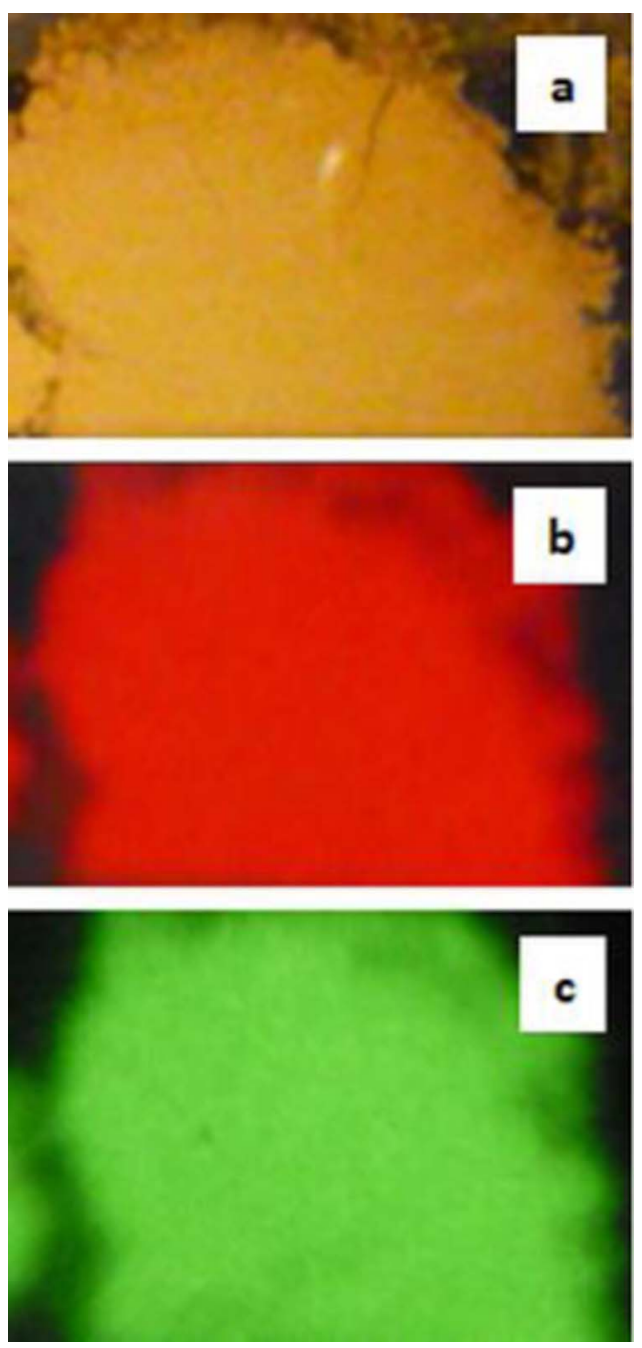

Figure 9. Optical images of $\mathrm{Zn}_{0.4} \mathrm{Cd}_{0.6} \mathrm{~S}: \mathrm{Cu}_{0.03} \mathrm{Al}_{0.03}$ phosphor (a) white light illumination, (b) red emission under $366 \mathrm{~nm}$ exciting light and (c) infrared emission of image (b) observed through a night vision goggle using a long wave pass filter, $900 \mathrm{~nm}$ cut-on). Width of all images $2 \mathrm{~cm}$.

Device fabrication and testing.-Recently we have carried out studies using blue laser diodes to assess the performance of phosphor screen and yttrium aluminum garnet crystals doped with cerium. ${ }^{37-39}$ To test the possible application of the phosphors for marking at night a sample of $\mathrm{Zn}_{0.4} \mathrm{Cd}_{0.6} \mathrm{~S}: \mathrm{Cu}_{0.03}, \mathrm{Al}_{0.03}$ was made up by putting the powder between two glass microscope slides as seen in Figure 9a, the body color of the phosphor is orange-brown under white light illumination. In Figure 9b the sample from 9a is seen under $366 \mathrm{~nm}$ light excitation, its emission in the visible region is deep red. In Figure 9c the same sample is seen through a night vision system where the visible light is filtered out using a long wave pass filter with a $900 \mathrm{~nm}$ cut-on (which eliminates all the wavelengths below $900 \mathrm{~nm}$ ) allowing observation of the pure infrared emission of the phosphor. In Figure $10 \mathrm{a}$ the same screen from Figure 9 is excited by a $0.5 \mathrm{~mW}$ laser diode emitting at $445 \mathrm{~nm}$; the red emission is flooded by the blue emission of the laser diode. Figure $10 \mathrm{~b}$ shows the same screen as used in Figure 10a excited with the laser diode but using a filter with a cutoff from $315 \mathrm{~nm}$ to $455 \mathrm{~nm}$ to eliminate the laser diodes blue emission, again the emission is deep red. In Figure 10c the sample is imaged through the night vision system with both filters in place. The images presented in Figures 10a-10c show that the emission is very bright where the area that the laser diode beam directly strikes the sample, this results in the digital camera saturating producing a perceived white emission. The surrounding areas not directly excited by the laser 

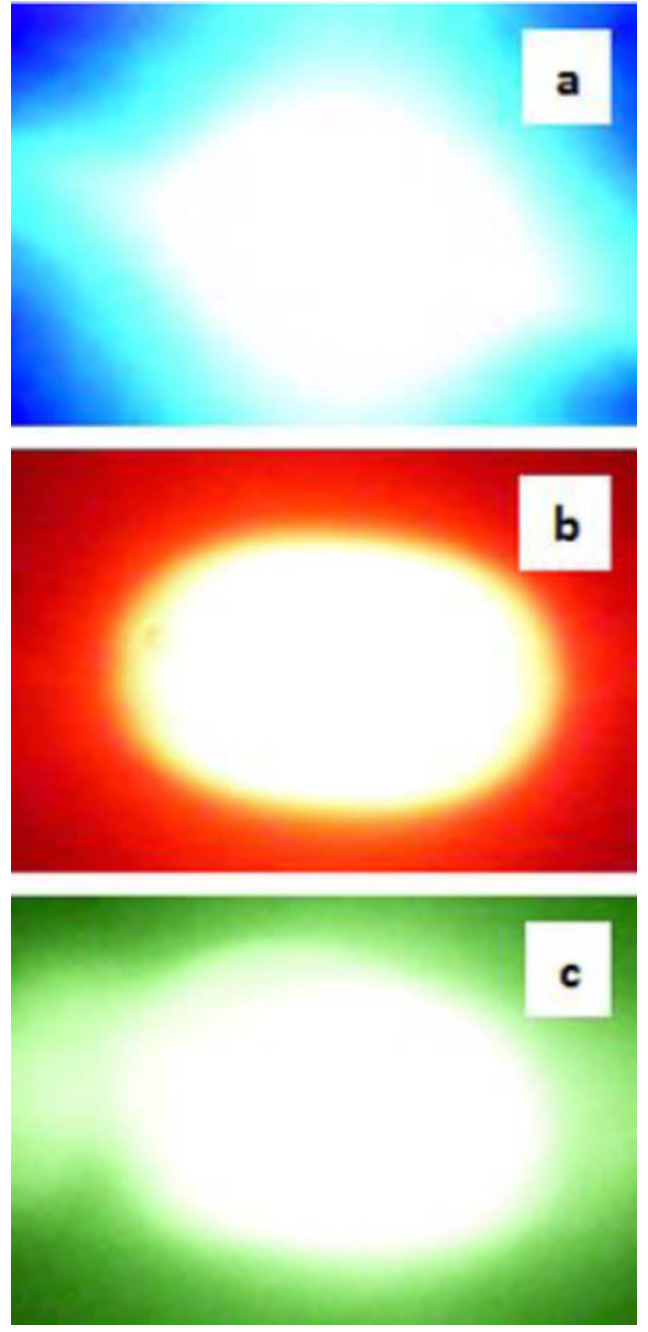

Figure 10. Optical images of $\mathrm{Zn}_{0.4} \mathrm{Cd}_{0.6} \mathrm{~S}: \mathrm{Cu}_{0.03} \mathrm{Al}_{0.03}$ phosphor excited using the blue emitting laser diode (a) no filter, (b) red emission using a filter (cutoff from $315 \mathrm{~nm}$ to $535 \mathrm{~nm}$ ) to eliminate the blue light (c) infrared emission of image (b) observed through a night vision goggle using the filter used in previous image and a long wave pass filter (900 nm cut-on). Width of all images $2 \mathrm{~cm}$.

shows the deep red emission in Figure 10b and the secondary green emission of the $\mathrm{Gd}_{2} \mathrm{O}_{2} \mathrm{~S}$ : Tb night vision phosphor screen showing the pure infrared emission above $900 \mathrm{~nm}$ in Fig. 10b. Figures 9 and 10 illustrate the viability of the phosphors for marking/coding using UV or laser diode light sources. Thus we have clearly demonstrated that the remote excitation of these phosphors using UV or visible emitting laser-diodes is a practical possibility. These infrared emitting powder phosphors are thus able to meet marking and coding requirements, especially in low light and poor visibility.

\section{Conclusions}

The facile synthesis and broad excitation range of $\mathrm{Zn}_{1-\mathrm{x}} \mathrm{Cd}_{\mathrm{x}} \mathrm{S}$ : $\mathrm{Cu}, \mathrm{Al}, \mathrm{Cl}$ phosphors has been presented herein. The phosphors remain stable in the atmosphere for many years when stored as powders in polymer bags.

The broad excitation band stretching from the deep red allows many different wavelengths of light to be used to excite these phosphors to generate infrared emission. Herein we have demonstrated that blue, green, yellow and orange light as well as UV will excite the phosphors. The blue region of the visible spectrum allows the use of blue light emitting LEDs to be used as backlights, and the excitation band at $365 \mathrm{~nm}$ means that UV LEDs, UV laser diodes and UV lamps could be used as excitation sources. The emission band at $1000 \mathrm{~nm}$ was sufficiently far into the infrared region to minimize the emission of visible light, and at the same time support detection by night vision systems. Fine tuning the zinc-cadmium ratio allows the fine tuning of the emission wavelength. Co-doping with $\mathrm{Al}^{3+}$ increased the infrared emission intensity up to more than twice that of the equivalent $\mathrm{ZnCdS}: \mathrm{Cu}, \mathrm{Cl}$ phosphor (without $\mathrm{Al}^{3+}$ co-doping).

We have shown that the $\mathrm{Al}^{3+}$ co-doping leads to cells with smaller volumes, and have suggested that the decrease in volume may be the factor that is responsible for the favorable changes in the PL properties

Finally we have shown herein that these infrared emitting powder phosphors are thus able to meet marking and coding requirements, especially in low light and poor visibility.

\section{Acknowledgments}

The authors are grateful to the UK Technology Strategy Board and the EPSRC for funding the PURPOSE, PRISM and ACTIVEL programs.

\section{References}

1. S. Shionoya, in Phosphor Handbook, 2nd ed., W. M. Yen, S. Shionoya, and H. Yamamoto, Editors, p. 262, CRC Press, Boca Raton (2007).

2. S. Shionoya, in Phosphor Handbook, 2nd ed., W. M. Yen, S. Shionoya, and H. Yamamoto, Editors, p. 256, CRC Press, Boca Raton (2007).

3. N. J. Werring, A. Vecht, and J. W. Fletcher, Brit. J. Appl. Phys. (J. Phys. D), 2, 509 (1969).

4. S. Tiwari, S. Mishra, and B. P. Chandra, Bull. Mater. Sci., 17, 1457 (1994).

5. S. Tiwari, S. Tiwari, B. K. Sahu, and B. P. Chandra, Bull. Mater. Sci., 18, 503 (1995).

6. W. Lehmann, J. Electrochem. Soc., 113, 449 (1966).

7. A. Vecht, J. Silver, R. Withnall, and G. R. Fern, ARO-ERO Phosphors for Marking, Coding, and Information, DARPA Report, R+D 9350 EE01, (2004).

8. J. Silver, P. J. Marsh, and G. R. Fern, Studies on the Infrared Emitting ZnCdS:Cu, In, Cl Phosphors -Phosphors for Marking, Coding, and Identification. International Display Workshop, Otsu, Japan, 9th-11th December, 2015, Proc IDW 514 (2015).

9. P. J. Marsh, J. Silver, and G. R. Fern, $\mathrm{ZnCdS}: \mathrm{Cu}, \mathrm{Al}, \mathrm{Cl}$ : A Near Infra-Red Emissive Phosphor for Marking, Coding, and Identification. 228th ECS Meeting (October 11-15, 2015), Phoenix, Arizona, USA.

10. Y. Y. Chen, J. G. Duh, B. S. Chiou, and C. G. Peng, Thin Solid Films, 392, 50 (2001).

11. L. Qi, B. I. Lee, J. M. Kim, J. E. Jang, and J. Y. Choe, J. Lumin., 104, 261 (2003).

12. J. H. Park, B. W. Park, K. W. Park, J. S. Kim, G. C. Kim, J. H. Hoo, and I. Yu, Solid State Commun., 148, 573 (2008),

13. S. J. Lee, J. E. Jang, Y. W. Jin, G. S. Park, S. H. Park, N. H. Kwon, Y. J. park, J. E. Jung, N. S. Lee, J. B. Yoo, J. H. You, and J. M. Kim, J. Electrochem. Soc, 148, H139 (2001)

14. T. T. Ngyuen, X. A. Trinh, L. H. Ngyuen, and T. H. Pham, Adv. Nat. Sci.: Nanosci. Nanotechnol., 2, 035008 (2011)..

15. K. Manzoor, S. Johny, D. Thomas, S. Setua, D. Menon, and S. Nair, Nanotechnology, 20, 065102 (2009).

16. J. Pichaandi and F. C. J. M. van Veggel, Coordin. Chem Rev., 263, 138 (2014).

17. G. X. Liang, L. L. Li, H. Y. Liu, J. R. Zhang, C. Burda, and J. J. Zhu, Chem. Commun., 46, 2974 (2010)

18. Z. Deng, O. Schulz, S. Lin, B. Ding, X. Liu, X. X. Wei, R. Ros, H. Yan, and Y. Liu, J. Am. Chem. Soc., 132, 5592 (2010).

19. L. Li, Y. Chen, Q. Lu, J. Ji, Y. Shen, M. Xu, R. Fei, G. Yang, K. Zhang, J. R. Zhang, and J. J. Zhu, Sci. Rep., 3, 1529 (2013).

20. Z. Wan, W. Luan, and S. T. Tu, J. Colloid Interf. Sci., 356, 78 (2011).

21. W. Zhang, H. Zhang, Y. Feng, and Z. Zhong, ACS Nano, 6, 11066 (2012).

22. H. Kumar, M. Kumar, P. B. Barman, and R. R. Singh, Appl. Phys. A, 117, 1249 (2014).

23. S. Coe-Sullivan, SID Int. Symp. Digest Tech. Papers, 46, 170 (2015).

24. D. Bera, L. Qian, T. K. Tseng, and P. H. Holloway, Materials, 3, 2260 (2010).

25. P. M. Allen, W. Liu, V. P. Chauhan, J. Lee, A. Y. Ting, D. Fukumura, R. K. Jain, and M. G. Bawendi, J. Am. Chem. Soc., 132, 470 (2010).

26. Y. T. Lim, S. Kim, A. Nakayama, N. E. Stott, M. G. Bawendi, and J. V. Frangioni, Mol. Imaging, 2, 50 (2003).

27. X. H. Gao, Y. Y. Cui, R. M Levenson, L. W. K. Chung, and S. M. Nie, Nat. Biotechnol., 22, 969 (2004).

28. A. M. Smith, M. C. Mancini, and S. Nie, Nat. Nanotech., 4, 710 (2009).

29. S. Kim, Y. T. Lim, E. G. Soltesz, A. M. De Grand, J. Lee, A. Nakayama, J. A. Parker, T. Mihaljevic, R. G. Laurence, D. M. Dor, L. H. Cohn, M. G. Bawendi, and J. V. Frangioni, Nat. Biotechnol., 22, 93 (2004).

30. H. C. Choi, W. Liu, P. Misra, E. Tanaka, J. P. Zimmer, B. I Ipe, M. G Bawendi, and J. V. Frangioni, Nat. Biotechnol., 25, 1165 (2007).

31. A. M. Smith and S. Nie, Nat. Biotechnol., 27, 732, (2009).

32. H. S. Choi, W. Liu, F. Liu, K. Nasr, P. Misra, M. Bawendi, and J. V. Frangioni, Nat. Nanotech., 5, 42 (2010). 
33. D. A. Davies, J. Silver, A. Vecht, P. J. Marsh, and J. A. Rose, J. Electrochem. Soc., 148, H143 (2001).

34. R. Withnall, J. Silver, M. Ghazli, C. Catherall, and J. J. Ojeda, International Displays Workshops, 1727, (2012)

35. I. Dev, L. J. Van Ryuven, and F. Williams, J. Appl. Phys. Sci., 39, 3344 (1968).

36. S. Shionoya, in Phosphor Handbook, 2nd ed., W. M. Yen, S. Shionoya, and H. Yamamoto, Editors, pp. 256, CRC Press, Boca Raton (2007)
37. A. Salimian, J. Silver, G. R. Fern, M. Evans, and R. Haghpanahan, ECS J. Solid State Sci. Technol., 5, R3001 (2016).

38. A. Salimian, G. R. Fern, H. Upadhyaya, and J. Silver, ECS J. Solid State Sci. Technol., 5, R26 (2016)

39. A. Salimian, J. Silver, G. R Fern, H. Upadhyaya, A. Metcalfe, T. G. Ireland, P. Harris, and R. Haghpanahan, ECS J. Solid State Sci. Technol., 5, R172 (2016). 